\title{
Potential Protective Effects of Propolis against Hepatotoxicity and Nephrotoxicity Induced by Monosodium Glutamate in Rabbits
}

\author{
Mokhtar Ibrahim Yousef ${ }^{1}$, Doaa El-Sayed El-Nassag ${ }^{2}$, Mahmoud Hussein Gasser ${ }^{3}$, Alaa F.M.Ibrahim ${ }^{3}$
}

\begin{abstract}
Monosodium glutamate (MSG) is used to enhance the flavour in the preparation of food to improvement the palatability. However, it induces oxidative stress and causes many health complications. This work determines the effect of MSG on kidney and liver functions and to know the protective role of propolis in male rabbits. Twenty rabbits were divided into four equal groups. Group (1) used as control, group (2) received propolis $(8 \mathrm{mg} / \mathrm{kg}$ body weight), group (3) received MSG (50 $\mathrm{mg} / \mathrm{kg}$ bodyweight) and group (4) received propolis $(8 \mathrm{mg} / \mathrm{kg}$ body weight) plus MSG (50mg/kg bodyweight) in the same time as combination group. The doses was given every other day for 12 weeks. Monosodium glutamate significantly elevated the concentration of thiobarbituric acid reactive substances (TBARS) and significantly decreased the concentration of reduced glutathione (GSH) and antioxidant enzymes (Catalase(CAT), Superoxide dismutase (SOD), Glutathione S-transferase (GST), Glutathione peroxidase (GPx)) in plasma, kidney and liver. Activities of liver enzymes (lactate dehydrogenase (LDH), aspartate transaminase (AST), alkaline phosphatase (AIP), gama-glutamyl transferase (GGT), acid phosphatase (AcP) and alanine transaminase (ALT)), creatinine, glucose and urea were enhanced significantly, while globulin, albumin and total protein were reduced in plasma. Also, treatment with MSG resulted in the deterioration of the histological architecture in liver and kidney. The combination group alleviated its adverse effects on liver and kidney, and this protection might be due to the antioxidant properties of propolis. In addition, the histology of liver and kidney results were supported by the biochemical findings. From the obtained results, it could be concluded that propolis capable to mitigate the oxidative stress, hepatotoxicity and nephrotoxicity induced by MSG in male rabbits.
\end{abstract}

Keywords: Monosodium glutamate; Propolis; Hepatotoxicity; Nephrotoxicity; Oxidative stress; Antioxidant enzymes; Histological examination; Male rabbits.

\footnotetext{
DOI: 10.21608/asejaiqjsae.2019.26639

${ }^{1}$ Department of Environmental Studies, Institute of Graduate Studies and Research, Alexandria University, Alexandria, Egypt.

${ }^{2}$ Department of Home Economics, Faculty of Specific Education, Alexandria University, Alexandria, Egypt..

${ }^{3}$ Department of Food Toxicology, Regional Center for Food and Feed, Agriculture Research Center, Alexandria, Egypt.
}

Received December 26, 2019, Accepted February 5, 2019

\section{INTRODUCTION}

Several of food additives recently are used in new technology foods such as tinned foods, ready to eat, Chinese, Japanese and packaged foods (Dixit et al., 2014). Also, they reported that most food additives use as flavour enhancers or preservatives. Boutry et al., (2011) mentioned that Monosodium glutamate (MSG) used to processed food, canned vegetables, mixed with foods during preparation, soups, Chinese food and enhance the flavour by stimulating the sensory receptors, therefore improve food palatability. Also, Diniz et al., (2005) mentioned that MSG is a popular food enhancer, which many manufacturers believe, can be used, as the consumer likes.

In addition, Sano, (2009) mentioned that MSG dissolves in saliva or water and quickly decompose to free sodium and glutamate ions. Beyreuther et al., (2007) reported that glutamate is added to food about 1 $\mathrm{g}$ in daily intake in European countries and about $4 \mathrm{~g}$ in Asia. Furthermore, Nakanishi et al., (2008) reported that average daily intake of Monosodium glutamate is about $10 \mathrm{~g}$ and is increasing. Consumption of MSG has increased in recent decades and the average daily intake about 10 g. Onyema et al., (2012) confirmed that the treated with MSG has number of adverse effects causes some alterations in hepatic glucose metabolism. Also, Geha et al., (2001) mentioned that some symptoms maybe resulted by use MSG such as flushing, headaches, numbness, sweating and weakness. Also, ingestion of MSG causes various complications including urticaria, asthma, neuropathy, atopic dermatitis and abdominal discomfort. Moreover, Cekic et al., (2005) indicated that pathological changes in hypothalamus, adrenal gland, and thymus can produce by administration of monosodium glutamate. Furthermore, rats treated with MSG showed obesity, cardiovascular dysfunction, and retinal lesions. While, diabetes mellitus, pancreatic hypertrophy and 
steatohepatitis were observed in mice treated with MSG (Sasaki et al., 2009; Cunha et al., 2010).

Degenerative changes and lipid peroxidation are produced in kidney of rats induced by MSG (Ortiz et al., 2006). Also, Abass and El-Haleem (2011) confirmed that oral treatment of MSG showed morphological alterations and oxidative stress in kidney tissues. Moreover, Poli et al., (2004) mentioned that cellular damage can produce from oxidative stress in tissues Thus, Havsteen (2002) confirmed that MSG causes oxidative stress and generates reactive oxygen species via the reduction of antioxidants in kidney, which leading to cellular injury and oxidation of proteins and lipids.

Oxidative stress related disorders and organ toxicity can be prevented by intake of antioxidants (Havsteen, 2002). In addition, Kamalkkannan et al., (2005) suggested that many natural and synthetic antioxidants can be use to prevent lipid oxidation. Bankova et al., (2000) and Sforcin (2007) mentioned that propolis is a traditional herb medicine in many countries. There are more than 300 components have been found in it, most of them are composed of phenolic compounds, essential oil and terpenes. Furthermore, Bankova (2005) reported that propolis has been shown to have many vital activities that are immune regulatory, anti-tumor, antioxidative, anti-inflammatory and hepatoprotective. Digestive tract disorders, blood system, Cardiovascular, cancer, dermatological disorders and respiratory disorders can be treated by Propolis (Saleh, 2012; Nakamura et al., 2013).In addition, Araujo et al., (2012); Mahmoud and Mahmoud, (2013) reported that propolis has many pharmacological properties like antioxidant, anti-inflammatory, antibacterial, antiviral, anticarcinogenic

\section{MATERIALS AND METHODS}

\section{Chemicals}

Mono sodium glutamates, Propolis were supplied from El Dawlia for Chemicals Company and Medical Equipments, Egypt, and California Health Products, Inc. 11577W. CA90064. Los Angeles. Olympic Bivd, respectively.

\section{Experimental groups and Animals}

In the present work, Male V-line rabbits (initial weight of $3.200 \pm 0.083 \mathrm{Kg}$ and age of 6-7 months) were used. Rabbits were obtained from the High Institute of Public Health, Alexandria University. Egypt. The animals were housed in cages. Water and Feed were provided ad libitum. Commercial pellets were provided for rabbits (Childs et al., 2002).
Twenty rabbits were divided into four equal groups. Group (1) used as control, group (2) received propolis (8mg/kg body weight), group (3) received MSG (50 $\mathrm{mg} / \mathrm{kg}$ bodyweight) and group (4) received propolis ( $8 \mathrm{mg} / \mathrm{kg}$ body weight) plus MSG (50mg/kg bodyweight) in the same time as combination group. propolis and MSG doses were calculated according to body weight of animals. Propolis and MSG was treated orally using syringe. The doses was given day after day for 12 weeks

\section{Blood samples collection and tissue preparations}

From the ear vein of all rabbits the blood were collected at the finale of 4th, 8th and 12th week throughout the 12-week experimental time in tubes with heparin (anti-coagulant). The centrifuge of sample sat $860 \mathrm{Xg}$ for $20 \mathrm{~min}$ was used to obtain the plasma, and were stored at $-80^{\circ} \mathrm{C}$ until used for analyses.

Animals were sacrificed at the end of treatment period. Kidney and liver were removed; chilled saline solution was used to wash the tissue, minced, homogenized $(10 \%, \mathrm{w} / \mathrm{v})$, centrifuged at $10,000 \mathrm{Xg}$ for 20 min at $4{ }^{\circ} \mathrm{C}$, stored at $-80{ }^{\circ} \mathrm{C}$ for the determination of tested parameters.

\section{Oxidative stress markers}

Plasma, kidney and liver Glutathione peroxidase (GPx), Superoxide dismutase (SOD), Glutathione Stransferase (GST), Catalase(CAT), glutathione(GSH) and thiobarbituric acid reactive substances (TBARS) were measured by Biodiagnostic Kit, Egypt.

\section{Biochemical parameters}

Plasma total protein, albumin, urea, creatinine and glucose were measured used kits from Barcelona; Spain, (Costa Brava 30), Biosystems S.A The activities of plasma lactate dehydrogenase (LDH), aspartate transaminase (AST), alkaline phosphatase (AlP), gamaglutamyl transferase (GGT), acid phosphatase (AcP) and alanine transaminase (ALT) were determined by kits from Barcelona; Spain, (Costa Brava 30), Biosystems S.A.

\section{Histological examination}

Liver and kidney tissue were dissected and the samples were fixed in 10\% formalin. Paraffin was used to stabilize the tissue and stained by hematoxylin and eosin (H\&E) to examine the tissue under the light microscope( Kulalou et al., 2004).

\section{Statistical analysis}

Data were analyzed as a completely randomized design (Steel and Torrie, 1981) using the General Linear Model procedure of SAS (1986). Means were statistically compared using least significant difference (LSD) test at 0.05 significant levels (Steel and Torrie, 1981). 


\section{RESULTS}

Lipid peroxidation (LPO) was assessed by measuring thiobarbituric acid-reactive substances (TBARS) levels in plasma, kidney and liver of male rabbits treated with monosodium glutamate (MSG), propolis and their combination at the finale of experimental time. Tables (1) and (2), Figure (1) showed that treatment with monosodium glutamate (group 3) significantly $(\mathrm{p} \leq 0.05)$ increased the TBARS concentration, and significantly $(\mathrm{p} \leq 0.05)$ decreased the activities of Catalase(CAT), Superoxide dismutase (SOD), Glutathione S-transferase (GST), Glutathione peroxidase (GPx) and the level of glutathione(GSH) in plasma, kidney and liver as compared to control group (group 1). Moreover, treatment with propolis in combination group (group 4) minimized effect of MSG on all of the previous parameters as compared to MSG group (group 3). Furthermore, treatment with propolis (group 2) significantly $(p \leq 0.05)$ minimized TBARS concentration and enhanced GSH level and CAT, SOD, GST and GPx activities compared to control group (group 1).

Lactate dehydrogenase (LDH), aspartate transaminase (AST), alkaline phosphatase (AlP), gamaglutamyl transferase (GGT), acid phosphatase (AcP) and alanine transaminase (ALT) were determined in plasma of male rabbits treated with MSG, propolis and their combination during the 12-week trial period. Figure (2) showed that treatment with monosodium glutamate (group 3) significantly $(\mathrm{p} \leq 0.05)$ elevated plasma $\mathrm{LDH}$, AST, AIP, GGT, AcP, and ALT when compared to control group (group 1). While, treatment with propolis in combination group (group 4) alleviated the effect of MSG on plasma enzymes compared to MSG group (group 3). While, treatment with Propolis (group 2) caused a decrease in plasma LDH, AST, AlP, GGT, $\mathrm{AcP}$, and ALT activities.

Table 1. Mean values \pm SE of liver TBARS and antioxidant enzymes of male rabbits treated with propolis (Pro), monosodium glutamate (MSG) and their combination

\begin{tabular}{lcccc}
\hline & \multicolumn{4}{c}{ Experimental groups } \\
\cline { 2 - 5 } Parameter & Control & Pro & MSG & MSG+ Pro \\
\hline TBARS & $34.37 \pm 0.557^{\mathrm{c}}$ & $26.81 \pm 0.434^{\mathrm{d}}$ & $50.87 \pm 0.824^{\mathrm{a}}$ & $45.72 \pm 0.74^{\mathrm{b}}$ \\
GSH & $6.37 \pm 0.096^{\mathrm{b}}$ & $7.90 \pm 0.119^{\mathrm{a}}$ & $3.25 \pm 0.049^{\mathrm{d}}$ & $4.08 \pm 0.061^{\mathrm{c}}$ \\
GPx & $35.28 \pm 0.984^{\mathrm{b}}$ & $43.15 \pm 0.999^{\mathrm{a}}$ & $16.91 \pm 0.950^{\mathrm{d}}$ & $22.68 \pm 0.961^{\mathrm{c}}$ \\
CAT & $51.42 \pm 0.441^{\mathrm{b}}$ & $64.27 \pm 0.551^{\mathrm{a}}$ & $26.22 \pm 0.225^{\mathrm{d}}$ & $32.91 \pm 0.282^{\mathrm{c}}$ \\
GST & $1.78 \pm 0.019^{\mathrm{b}}$ & $2.19 \pm 0.023^{\mathrm{a}}$ & $0.87 \pm 0.009^{\mathrm{d}}$ & $1.09 \pm 0.011^{\mathrm{c}}$ \\
SOD & $26.68 \pm 0.141^{\mathrm{b}}$ & $33.09 \pm 0.175^{\mathrm{a}}$ & $13.07 \pm 0.069^{\mathrm{d}}$ & $17.34 \pm 0.091^{\mathrm{c}}$ \\
\hline
\end{tabular}

$\mathrm{n}=5$ for each treatment group.

Mean values were significantly different $(\mathrm{p} \leq 0.05)$ within a row not sharing a common superscript letters $(\mathrm{a}, \mathrm{b}, \mathrm{c}, \mathrm{d})$

TBARS $(\mathrm{nmole} / \mathrm{gm}$ tissue $)=$ Thiobarbeturic acid reactive substances, GSH (u mole/gm tissue $)=$ Glutathione, GPx $(\mathrm{U} / \mathrm{mg}$ protein $)$

$=$ Glutathione peroxidase, CAT $(\mathrm{U} / \mathrm{mg}$ protein $)=$ Catalase, GST $(\mu \mathrm{mole} / \mathrm{hr} / \mathrm{mg}$ protein $)=$ Glutathione S-transferase and SOD

$(\mathrm{U} / \mathrm{mg}$ protein $)=$ Superoxide dismutase

Table 2. Mean values \pm SE of kidney TBARS and antioxidant enzymes of male rabbits treated with propolis (Pro), monosodium glutamate (MSG) and their combination

\begin{tabular}{lllll}
\hline & \multicolumn{4}{c}{ Experimental groups } \\
\cline { 2 - 5 } Parameter & Control & \multicolumn{1}{c}{ Pro } & MSG & MSG+ Pro \\
\hline TBARS & $21.07 \pm 0.581^{\mathrm{c}}$ & $16.43 \pm 0.435^{\mathrm{d}}$ & $32.03 \pm 0.883^{\mathrm{a}}$ & $28.87 \pm 0.796^{\mathrm{b}}$ \\
GSH & $6.10 \pm 0.148^{\mathrm{b}}$ & $7.23 \pm .093^{\mathrm{a}}$ & $3.11 \pm 0.076^{\mathrm{d}}$ & $3.97 \pm 0.096^{\mathrm{c}}$ \\
GPx & $25.64 \pm 0.368^{\mathrm{b}}$ & $30.70 \pm 0.342^{\mathrm{a}}$ & $13.36 \pm 0.430^{\mathrm{d}}$ & $16.97 \pm 0.412^{\mathrm{c}}$ \\
CAT & $65.12 \pm 5.325^{\mathrm{b}}$ & $79.50 \pm 4.728^{\mathrm{a}}$ & $33.21 \pm 2.716^{\mathrm{d}}$ & $42.98 \pm 3.514^{\mathrm{c}}$ \\
GST & $5.19 \pm 0.086^{\mathrm{b}}$ & $6.06 \pm 0.072^{\mathrm{a}}$ & $2.75 \pm 0.045^{\mathrm{d}}$ & $3.42 \pm 0.057^{\mathrm{c}}$ \\
SOD & $24.88 \pm 0.435^{\mathrm{b}}$ & $29.60 \pm 0.364^{\mathrm{a}}$ & $13.17 \pm 0.589^{\mathrm{d}}$ & $16.64 \pm 1.141^{\mathrm{c}}$ \\
\hline
\end{tabular}

$\mathrm{n}=5$ for each treatment group.

Mean values were significantly different $(\mathrm{p} \leq 0.05)$ within a row not sharing a common superscript letters $(\mathrm{a}, \mathrm{b}, \mathrm{c}, \mathrm{d})$

TBARS (nmole/gm tissue) $=$ Thiobarbeturic acid reactive substances, GSH (u mole/gm tissue) $=$ Glutathione, GPx (U/mg protein)

$=$ Glutathione peroxidase, CAT $(\mathrm{U} / \mathrm{mg}$ protein $)=$ Catalase, GST $(\mu$ mole $/ \mathrm{hr} / \mathrm{mg}$ protein $)=$ Glutathione S-transferase and SOD

$(\mathrm{U} / \mathrm{mg}$ protein $)=$ Superoxide dismutase . 


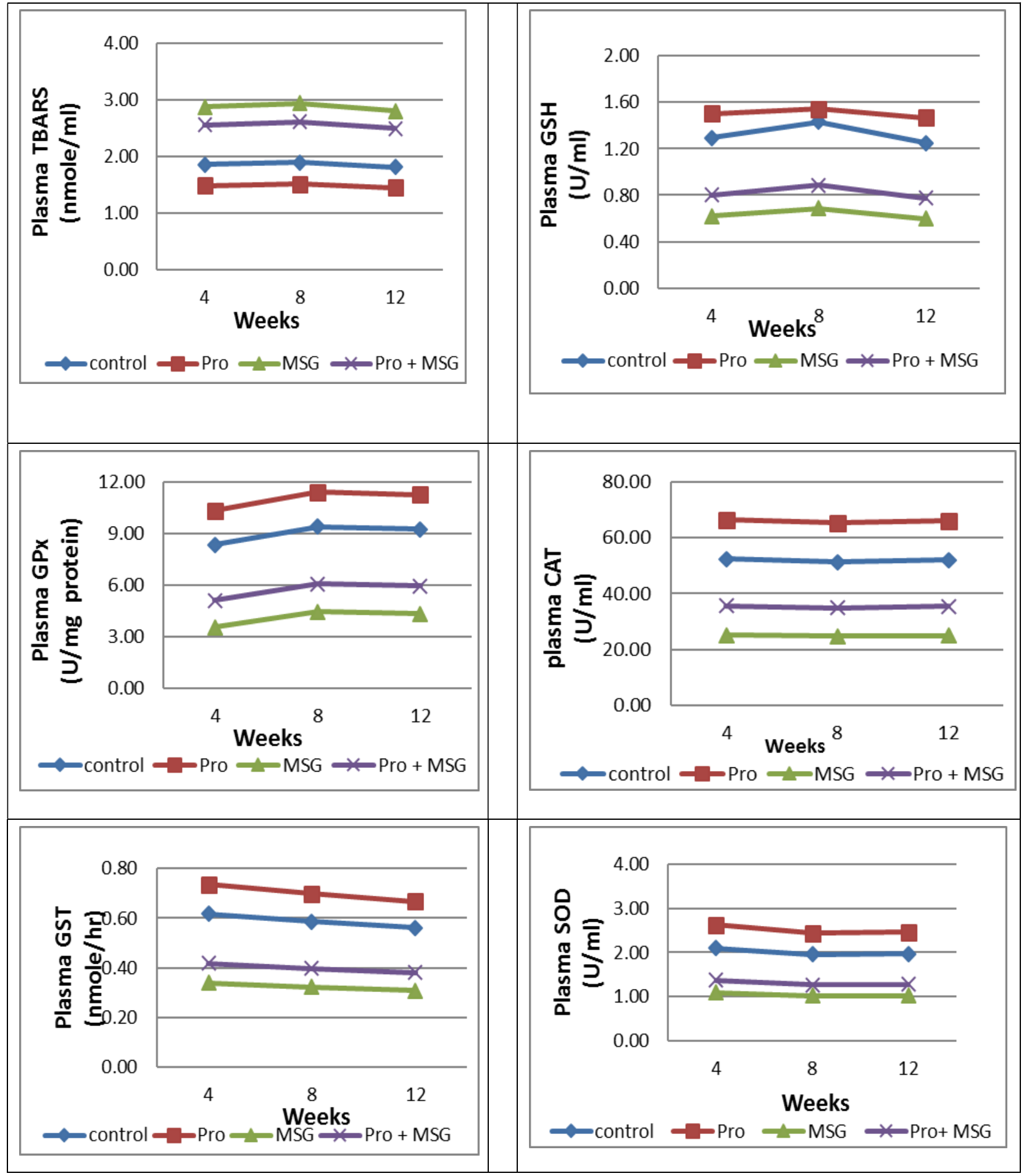

Figure 1. Changes in plasma activites of Catalase(CAT), Superoxide dismutase (SOD), Glutathione Stransferase (GST), Glutathione peroxidase (GPx) and the level of glutathione (GSH) and thiobarbituric acid reactive substances(TBARS) in male rabbits treated with monosodium glutamate (MSG), propolis (Pro) and their combination. 


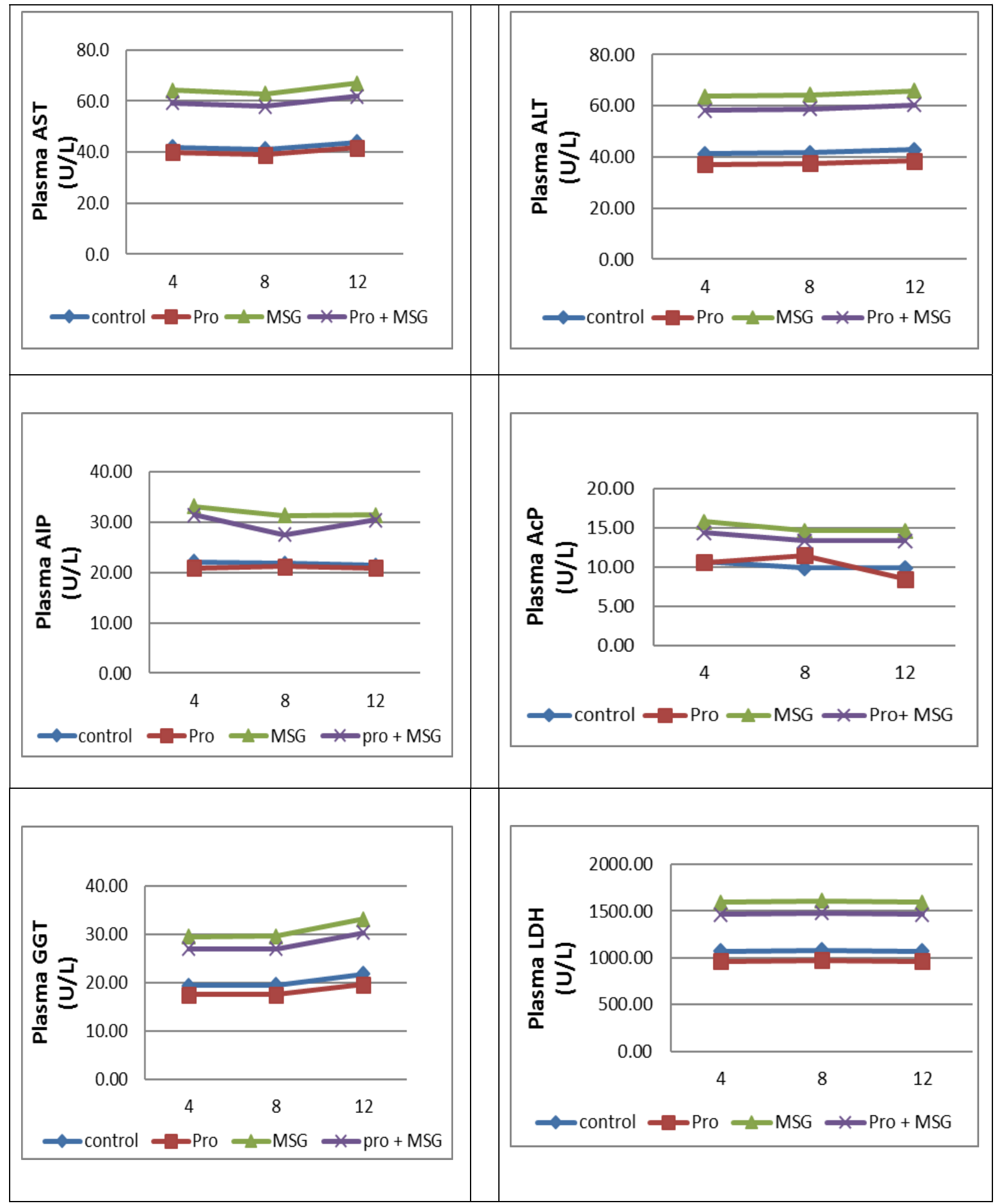

Figure 2. Changes in plasma lactate dehydrogenase (LDH), aspartate transaminase (AST), alkaline phosphatase (AIP), gama-glutamyl transferase (GGT), acid phosphatase (AcP) and alanine transaminase (ALT) in male rabbits treated with monosodium glutamate (MSG), propolis (Pro) and their combination. 
Plasma glucose level of male rabbits exposed to MSG, propolis and their combination represented in figure (3). The figure showed that treatment with MSG (group 3) caused a significant $(\mathrm{p} \leq 0.05)$ elevated in the concentration of plasma glucose than control group (group 1). Moreover, propolis treatment in combination group (group 4) caused a decrease in the increase of plasma glucose level as compared to MSG group (group 3 ). On the other hand, treatment with propolis (group 2) decreases glucose level.

Plasma globulin (G), albumin (A), total protein (TP), creatinine and urea were determined in 4th, 8th and 12th week. The figure (3) represented treatment with MSG (group 3) caused a significant $(\mathrm{p} \leq 0.05)$ reduce in plasma $\mathrm{G}, \mathrm{A}$ and TP and increased in urea and creatinine when comparing with control group (group 1). Moreover, the combination group (group 4) showed a decrease in the increase of plasma urea and creatinine. While, increase in the decrease of plasma G, A and TP as compared to MSG group (group 3). Also, treatment with propolis (group 2) elevated plasma level of G, A and TP and reduced creatinine and urea.

The histological examination of rabbits livers are represented in figure (4). The figure showed that liver formed of tubules of hepatocytes formed of bile duct, hepatic artery and portal vein separated by sinusoidal blood vessels in the control group (Figure 4 A) and propolis treated group (Figure $4 \mathrm{~B}$ ). Liver section taken from rabbits after treated with MSG represented in figure (4C1) and (4C2), showed hepatocytes damage was manifested by marked disturbance in hepatic architecture with hydropic change with dilation of sinusoidal blood vessels, the portal tract showed moderate portal inflammation precemeal necrosis and lytic necrosis, and congestion.

Liver section taken from MSG with propolis group appeared in figure (4D1) and (4D2), showed that improvement in hepatic architecture with mild hydropic change, mild sinusoidal dilation and mild portal inflammation.

The light micrographs of kidney tissues demonstrated in figure (5). Kidney section taken from control group (Figure 5A) and propolis treated group (Figure 5B) showed normal tubules and glomeruli. Kidney section taken from rabbits after treated with MSG represented in figure $(5 \mathrm{C} 1)$ and $(5 \mathrm{C} 2)$, revealed degeneration changes in tubular epithelium with flattening of epithelial lining. Presence of propolis with MSG showed improvement of glomeruli and tubules appeared in figure (5D1) and (5D2), showed mild glomerular capillary swelling and mild degeneration change in tubules.

\section{DISCUSSION}

Monosodium glutamate significantly elevated the concentration of TBARS and significantly decreased the concentration of reduced glutathione (GSH) and antioxidant enzymes. This result is comparable and confirmed by Selvakumar et al., (2006) who reported that high concentration of lipid peroxidation could be return to generation of ROS due to induces MSG, leading to injury of membrane function. Also, Gupta et al., (1992) mentioned that the high level of lipid peroxidation causes functional and structural inflammation of cellular membranes. Furthermore, Fadillioglu et al., (2004) suggested that accumulation of lipid peroxidation causes inflammation of tissue. Moreover, treatment with propolis in combination group minimized bad effect of MSG on antioxidants enzymes and TBARS, this result confirmed by Fadillioglu et al., (2004) who reported that propolis treatment accelerated repair mechanism of damaged cell membranes.

In addition, low concentration of glutathione Stransferase activity and glutathione level following MSG administration is similar to the finding by Andersen, (2004) who reported that MSG treatment caused depletion of tissue glutathione. Also, the reduction in GSH levels are in agreement with Onyema et al., (2006) who reported that low tissue levels of GSH occur due to lipid peroxidation resulting from MSG treatment. In our study, MSG group showed decreased activities of SOD and CAT enzymes, in MSG treated rabbits which is comparable with previous study of Singh et al., (2003) who mentioned that the decrease in the activity of these enzymes could result from their stop by ROS. Also, this result is comparable and confirmed by Abdel Baky et al., (2009) who mentioned that MSG causes the induction of oxidative stress in the liver.

The present results showed that MSG caused elevation in plasma AST and ALT. Mansour et al., (2002) confirmed this result and referred that the elevation of these enzymes in plasma due to the leakage of ALT and AST from the liver cystol into the blood. Moreover, Al-Mamary et al., (2002) reported that the high concentration activity of serum ALT probably be a marker of hepatic damage. This elevation might be mainly to the production of free radical caused damage of plasma membranes and mitochondrial resulting in release of this enzyme (Poli et al., 1990). The high concentration activity of GGT in MSG group is corroborated with previous study of Onyema et al., (2006) who reported that MSG caused oxidative stress resulting in liver damage. 


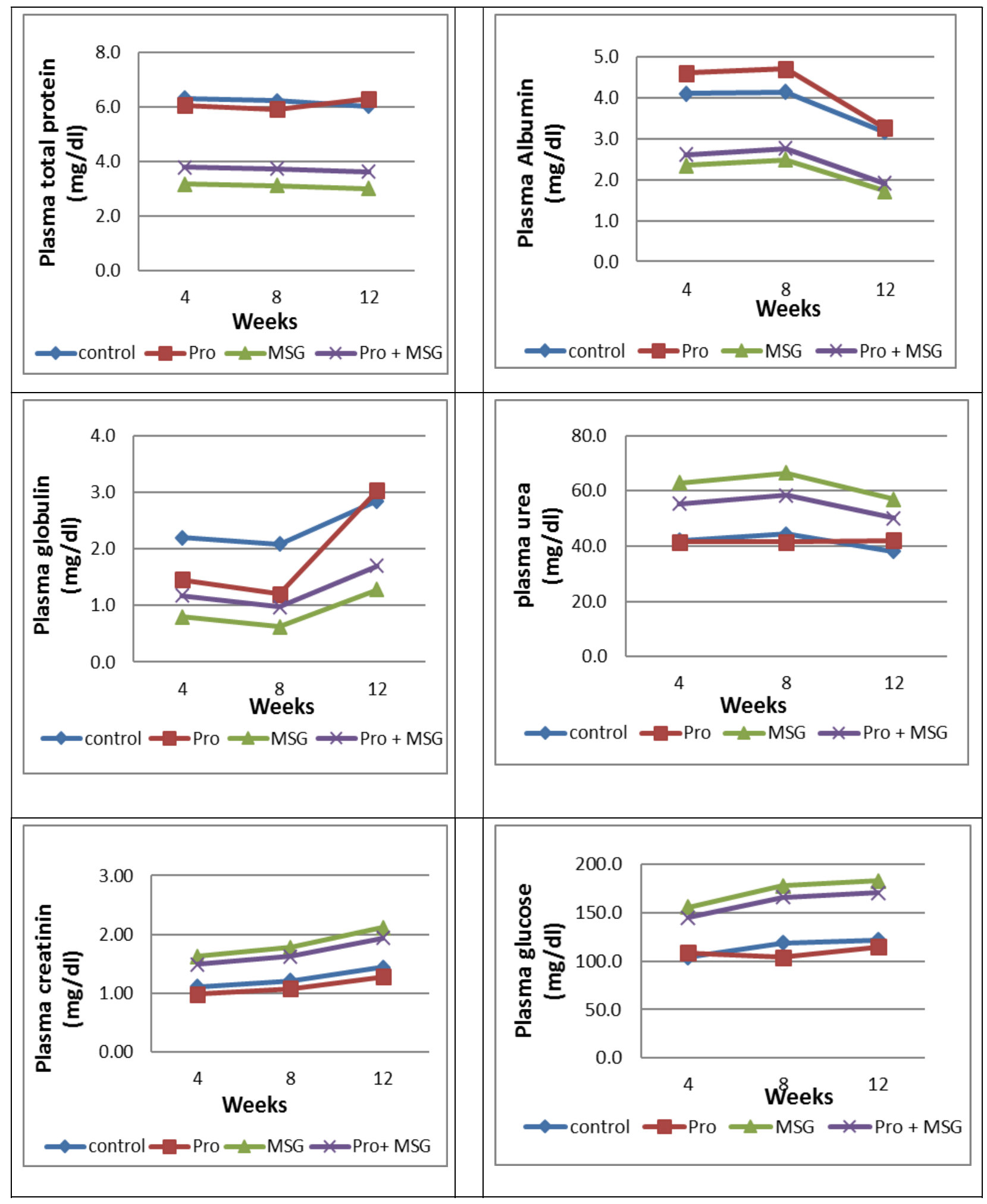

Figure 3. Changes in Plasma globulin (G), albumin (A), total protein (TP), creatinine, glucose and urea in male rabbits treated with monosodium glutamate (MSG), propolis (Pro), and their combination. 


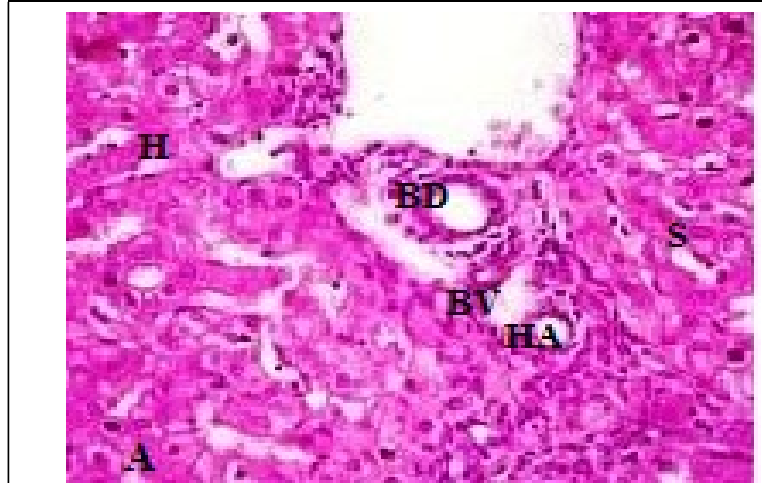

(A) Liver section of control group (group 1), showing liver formed of tubules of normal hepatocytes (H) formed of bile duct (BD), hepatic artery (HA) and portal vein (BV) separated by sinusoidal (S) blood vessels.

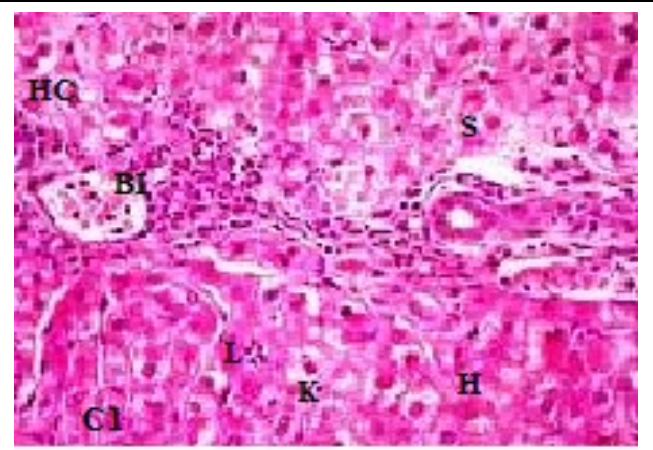

(C1) Liver section of MSG group (group 3), showing disturbance in hepatic architecture showing hydropic change (HC) with dilation of sinusoidal blood vessels, and the portal tract shows moderate portal inflammation (BI) precemeal necrosis and lytic necrosis $(L)$.

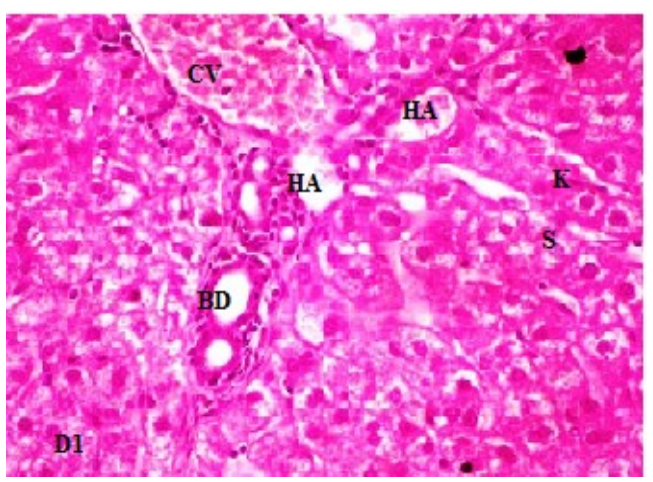

(D1) Section in the liver of propolis with MSG group (group 4), showing improvement in hepatic architecture showing mild hydropic change, mild sinusoidal dilation and mild portal inflammation.

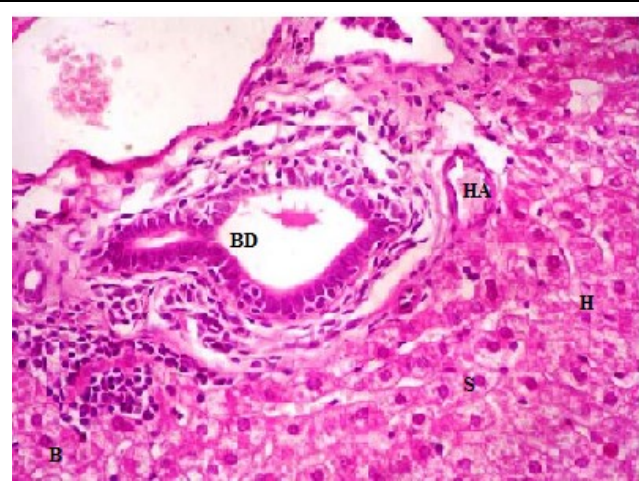

(B) Section in the liver of propolis (group 2), showing tubules of hepatocytes separated by sinusoidal blood vessels, there is portal tnets formed of bile duct (BD), hepatic artery (HA) and portal vein (BV).

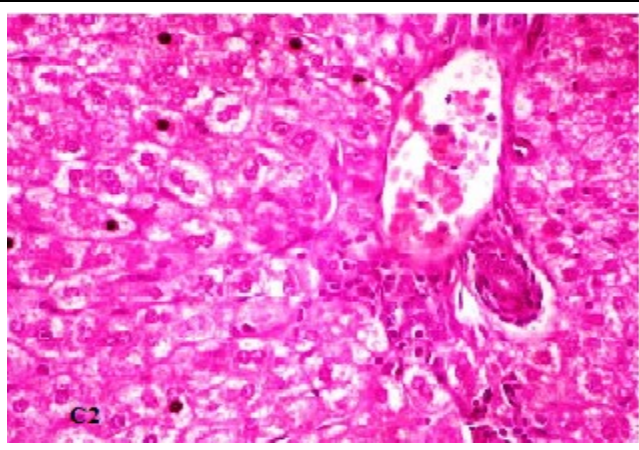

(C2) Liver section of MSG group (group 3), showing disturbance in hepatic architecture showing hydropic change (HC) with dilation of sinusoidal blood vessels, the portal tract shows moderate portal inflammation (BI) and congestion.

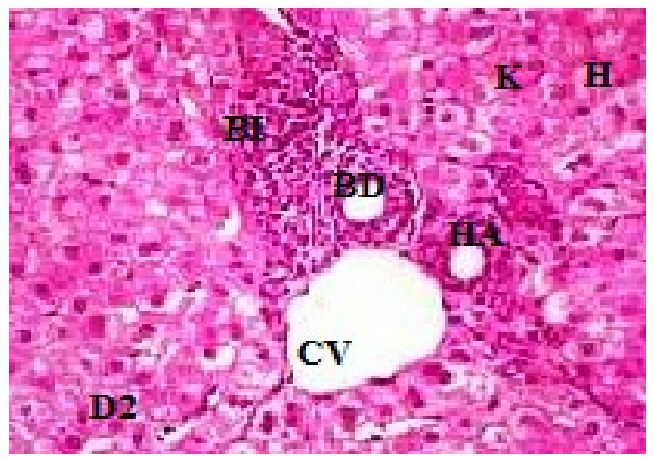

(D2) Section in the liver of propolis with MSG group (group 4), showing improvement in hepatic architecture showing mild hydropic change, sinusoidal dilation and moderate portal inflammation.

Figure 4. Photomicrograph of liver sections stained with H\&E. 


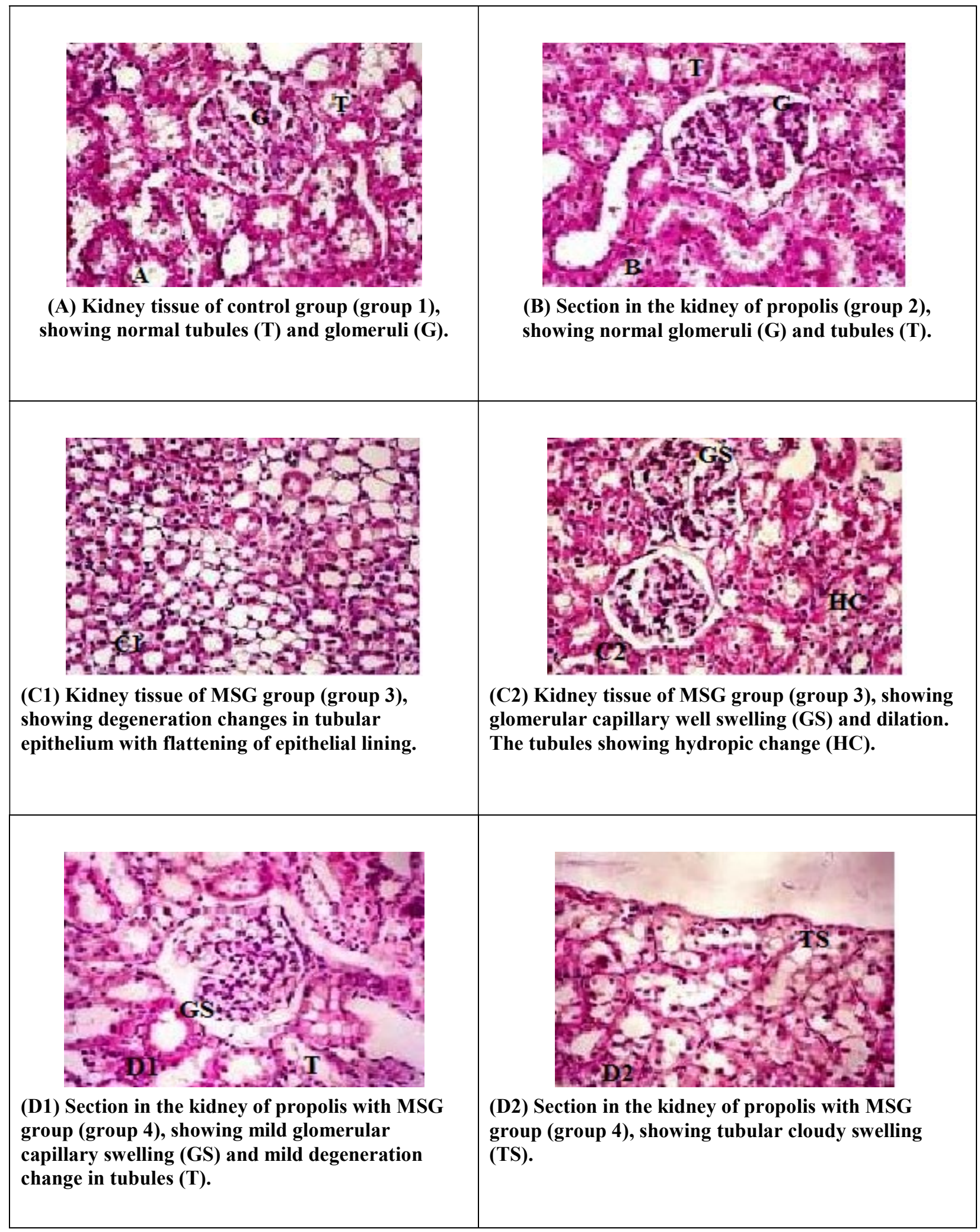

Figure 5. Photomicrograph of kidney sections stained with H\&E 
The reduction of albumin in the MSG treated rabbits is similar to the finding by Tawfik and Al-Badr (2012) who reported that MSG group showed reduced in serum albumin levels lower than control group. In addition, Vinodini et al., (2010) reported that treatment of MSG increase the concentration of urea and creatinine due to the kidney functional capacity, total or partial damage of kidney function of tubular excretion due to MSG could have interference with creatinine metabolism.

Treatment with propolis lead to significant reduction in lipid peroxides levels and increase in antioxidant enzymes GPx, GST, CAT and SOD than control group, indicating the protection of the liver tissues from the damaging effect of MSG. This result confirmed by Yagi (1987) who indicated that propolis group showed higher concentration of GSH, CAT and SOD than control group of mice. This is due to the ability of propolis to protect tissues from oxidative stress. In addition, Oktem et al., (2005) confirmed this result and mentioned that propolis is capable to improvement of antioxidant system by preventing oxidative damage. Also, this result is comparable with Banskota et al., (2000); Bhadauria, (2012) and Saleh, (2012) who indicated that propolis has high concentration of total phenolic compounds resulting in protective effect from hepatotoxicity. Moreover, this result confirmed by Newairy and Abdou, (2013) who reported that propolis considered lipid peroxidation inhibitor and free-radical scavenger because it has antioxidant property resulting in protected effect, increase antioxidant enzymes and elevation the intracellular concentration of glutathione.

Liver section taken from rabbits after treated with MSG showed hepatocytes damage was manifested by marked disturbance in hepatic architecture. This result is comparable and confirmed by Inuwa et al., (2011) who suggested that the change in the structure of the liver cells occurs through oral treatment with MSG. Presence of propolis showed improvement in hepatic architecture. This result is in agreement and confirmed by Araujo et al., (2012) who mentioned that propoils has antioxidant properties resulting in ameliorate fibrosis in hepatic architecture. The obtained result of kidney section from MSG group is corroborated with earlier study by Thomas et al., (2010) and Paul et al., (2012) who supported that MSG supplementation by oral intake induced kidney damage. Furthermore, Stajn et al., (1997) mentioned that MSG produces reactive oxygen substances resulting in cellular injury and oxidative stress, leading to lipid peroxidation which results in disintegration and destabilization of cell membrane.

Moreover, Eweka (2007) confirmed that treated with MSG leading to cellular necrosis of the renal glomerulus. In addition, Vinodini et al., (2010) recommended that oral treatment of MSG showed morphological alterations and oxidative stress in renal tissues. Presence of propolis with MSG showed improvement of glomeruli and tubules. This result confirmed by Araujo et al., (2012) who reported that propoils has antioxidant properties resulting in ameliorate fibrosis in kidney. Also, El-Kott and Owayss, (2008) and El-kott et al., (2012) mentioned that the propolis had anti proliferative and anticarcinogenic activity.

\section{CONCLUSION}

The results obtained showed deterioration in blood biochemical measurements, activities of antioxidant enzymes, liver and kidney functions and deterioration of liver and kidney tissues due to treatment with MSG. Also, the result showed that propolis has ability to improving the biochemical measurements and has the capacity as antioxidant by increases the activities of antioxidant enzymes and restore liver and kidney cells near their normal shape.

\section{REFERENCES}

Abass, M.A. and M.R.A. El-Haleem. 2011. Evaluation of monosodium glutamate induced neurotoxicity and nephrotoxicity in adult male albino rats. $J$ Am Sci 7: 264276.

Abdel Baky, N.A., A.M. Mohamed and L.M. Faddah. 2009. Protective effect of $\mathrm{N}$-acetyl cysteine and/or pro vitamin A against monosodium glutamate-induced cardiopathy in rats. J Pharmacol Toxicol 4:178-193.

Al-Mamary, M., M. Al-Habori, A. M. Al-Aghbari and M. M. Baker. 2002. Investigation into the toxicological effects of catha edulis leaves: A Short-term study in animals. Phytoetherapy Research 16: 127-132.

Andersen, J.K., 2004. Oxidative stress in neurodegeneration: cause or consequence. Nature reviews; Neuroscience, 5(suppl): 518-525.

Araujo, M.A.R., S.A. Libério, R.N.M. Guerra, M.N.S. Ribeiro and F.R.F. Nascimento. 2012. Mechanisms of action underlying the anti-inflammatory and immunomodulatory effects of propolis: a brief review. Braz. J. Pharmacognosy 22:208-219.

Bankova, V. S., S. L. De.Castro and M. C. Marcucci. 2000. Propolis: recent advances in research on chemistry and plant origin. Apidologie 31: 3-15.

Bankova, V. 2005. Recent trends and important developments in propolis research. Evidence-Based Complementary and Alternative Medicine 2(1): 29-32. 
Banskota, A.H., Y. Tezuka, I.K. Adnyana, K. Midorikawa, K. Matsushige, D. Message, A.A. Huertas and S. Kadota. 2000.Cytotoxic, hepatoprotective and free radical scavenging effects of propolis from Brazil, Peru, the Netherlands and China. J Ethnopharmacol. 72:239-246.

Beyreuther, K., H.K. Biesalski, J.D. Fernstrom, P. Grimm, W.P. Hammes, U. Heinemann, O. Kempski, P. Stehle, H. Steinhart and R. Walker. 2007. Consensus meeting: monosodium glutamate - an update. Eur J Clin Nutr 61: 304-313.

Bhadauria, M. 2012. Propolis prevents hepatorenal injury induced by chronic exposure to carbon tetrachloride. Evid Based Complement Alternat Med .Article ID 235358, 12 pages doi:10.1155/2012/235358

Boutry, C., H. Matsumoto, G. Airinei, R. Benamouzig, D. Tomé, F. Blachier and C. Bos. 2011. Monosodium glutamate raises antral distens ion and plasma amino acid after a standard meal in humans. Am $J$ Physiol Gastrointest Liver Physiol 300: G137-G145.

Cekic, S., M. Filipovic, V. Pavlovic, M. Ciric, M. Nesic, Z. Jovic and S. Brankovic. 2005. Histopathologic changes at the hypothalamic, adrenal and thymic Nucleus arcuatus in rats treated with monosodium glutamate. Acta Medica Medianae 44: 35-42.

Childs, A.C., S.L. Phaneuf, A.J. Dirks, T. Phillips and C. Leeuwenburgh. 2002. Doxorubicin treatment in vivo causes cytochrome $\mathrm{C}$ release and cardiomyocyte apoptosis, as well as increased mitochondrial efficiency, superoxide dismutase activity, and Bcl-2: Bax ratio. Cancer Res. 62: 4592-4598.

Cunha, N.V., S.B. de Abreu, C. Panis, S. Grassiolli, F.A. Guarnier, R. Cecchini, T.L. Mazzuco, P. Pinge-Filho and M.C. Martins-Pinge. 2010. Cox-2 inhibition attenuates cardiovascular and inflammatory aspects in monosodium glutamate-induced obese rats. Life Sci 87:375-381.

Diniz, Y.S., L.A.Faine, C.M. Galhardi, H.G. Rodrigues, G.X. Ebaid, R.C. Burneiko, A.C. Cicogna and E.L.B. Novelli. 2005. Monosodium glutamate in standard and highfiber diets: metabolic syndrome and oxidative stress in rats. Nutrition 21: 749-755.

Dixit, S.G., P. Rani, A. Anand, K. Khatri, R. Chauhan and V. Bharihoke. 2014. To study the effect of monosodium glutamate on histomorphometry of cortex of kidney in adult albino rats. Renal Failure 36(2):266-270.

El-kott, A.F., A .A. Kandeel, S.F. Abed El-Aziz, H.M. Ribea. 2012. Effects of bee honey on PCNA and P53 expression in the rat hepatocarcinogenesis. International Journal of Cancer Research 8:130-139.

El-Kott, A.F., A.A. Owayss. 2008. Protective effects of propolis against the amitraz hepatotoxicity in Mice. Journal of Pharmacology and Toxicology 3:402-408.

Eweka, A.O. 2007. Histological studies of the effect of monosodium glutamate on the kidneyof adult Wistar rats. Internet J. of Health 6(2): 1528-831.
Fadillioglu, E., E. Ortas, H. Erdogen, M. Yagmurca, S. Sogut, M. Ucar and M.K. Irmak. 2004. Protective effect of caffeic acid phenethyl ester on doxorubicin-induced cardio toxicity in rats. J Appl Toxicol 24:47-52.

Geha, R. S., A. Beiser, C. Ren, R. Patterson, L. C. Grammar, A. M. Ditto and K. E. Harris. 2001. Review of Allergic Reaction to Monosodium Glutamate and Outcome of a Multicenter Double Blind Placebo-Controlled Study. Journal of Nutrition 130: 1032S-1038S.

Gupta, V.K., V. Mallika, G.Yashik and D.K. Shrivastav. 1992. Oxygen derived free radicals in clinical context. Indian J Clin Biochem 7: 3-10.

Havsteen, B.H. 2002. The biochemistry and medical significance of the flavonoids. Pharmacol Ther 96:67202.

Inuwa, H.M., V.O. Aina, G. Baba, I.O. Aim and J. Leehman. 2011. Determination of nephrotoxicity and hepatoxicity of monosodium glutamate (MSG) consumption. British J. of Pharm and Tox 2(3):148-153: 2044-246.

Kamalkkannan, N., R. Rukkumani, K. Aruna, P.S. Varma, P. Viswanathan and P.V. Menon. 2005. Protective effect of $\mathrm{N}$-Acetyl Cysteine in carbon tetrachloride induced hepatotoxicity in rats. Iranian J Pharmacol Therapeut 4: 118-123.

Kulalou, I., M. Faid and A.T.Ahami. 2004. Extending shelf of fresh minced Camel meat at ambient temperature by Lactobacillus delbrueckii. J. Food Sci 7: 1-6.

Mahmoud, E.F., M.F. Mahmoud. 2013. Evaluation of The effect of Propolis extract on the Tongue mucosa of an Induced toxic rabbit by Fenitrothion. Life Science Journal 10:767-775. |

Mansour, H. A., A.S. Newairy, M.I.Yousef and S. A. Sheweita. 2002. Biochemical study on the effects of some egyptian herbs in alloxan-induced diabetic rats. Toxicology 170(3):221-228.

Nakamura, T., Y. Ohta, K. Ohashi, K. Ikeno, R. Watanabe, K. Tokunaga and N. Harada. 2013. Protective effect of brazilian propolis against liver damage with cholestasis in rats treated with alpha-Naphthylisothiocyanate. Evid Based Complement Alternat Med 302720.

Nakanishi, Y., K. Tsuneyama, M. Fujimoto, T.L. Salunga, K. Nomoto, J.L. An, Y. Takano, S. Iizuka, M. Nagata, W. Suzuki, T. Shimada, M. Aburada, M. Nakano, C. Selmi and M.E. Gershwin. 2008. Monosodium glutamate (MSG): a villain and promoter of liver inflammation and dysplasia. J Autoimmun 30: 42-50.

Newairy, A.A. and H.M. Abdou. 2013. Effect of propolis consumption on hepatotoxicity and brain damage in male rats exposed to chlorpyrifos. African Journal of Biotechnology 12, 5232-5243.

Oktem, F., F. Ozguner, O. Sulak, S. Olgar, O. Akturk, H.R. Yilmaz and I. Altuntas. 2005. Lithium induced renal toxicity in rats; protection by a novel antioxidant caffeic acid phenyl ethyl ester. Mol. Cell. Biochem 277:109-115. 
Onyema, O. O., E. O. Farombi, G. O.Emerole, A. I. Ukoha and G. O. Onyeze. 2006. Effect of Vitamin E on Monosodium Glutamate Induced Hepatoxicity and Oxidative Stress in Rats. Indian Journal of Biochemistry \& Biophysics 43(1):20-24.

Onyema, O.O., C. S. Alisi and A.P.Ihetuge. 2012. Monosodium Glutamate Induces Oxidative Stress and Affects Glucose Metabolism in the Kidney of Rats. International Journal of Biochemistry Research \& Review 2(1):1-11.

Ortiz, G.G., O.K.Bitzer-Quintero, C.B.Zrate, S. RodrguezReynoso, F. Larios-Arceo, I.E.Velzquez-Brizuela, F. Pacheco-Moisés and S.A. Rosales-Corral. 2006. Monosodium glutamate-induced damage in liver and kidney: a morphological and biochemical approach. Biomed Pharmacother 60:86-91.

Paul, M.V., M. Abhilash, M.V. Varghese, M. Alex and N. R. Harikumaran. 2012.Protective effects of alpha-tocopherol against oxidative stress related to nephrotoxicity by monosodium glutamate in rats. Toxicol Mech Methods 22: 625-630. doi:10.3109/15376516.2012.714008.

Poli, G., D. Cottalasso, M. A.Pronzato, E.Chiarpotto, F .Biasi, F. P.Corongiu, U. M. Marinari, G. Nanni and M. U. Dianzani. 1990. Lipid peroxidation and covalent binding in the early functional impairment of liver golgi apparatus by carbon tetrachloride. Cell Biochemistry \&Function 8(1): 1-10.

Poli, G., G.Leonarduzzi, F.Biasi and E.Chiarpotto. 2004. Oxidative stress and cell signalling. Curr Med Chem 11: 1163-1182.

Saleh, E.M. 2012. Antioxidant effect of aqueous extract of propolis on hepatotoxicity induced by octyl phenol in male rats. Acta Toxicol. Argent 20: 68-81.

Sano, C. 2009. History of glutamate production. Am J Clin Nutr 90:728S-732S.

SAS, Statistical Analysis System. 1986. SAS User's Guide: Statistics, version 5 Edition SAS Inst. Inc., Cary, NC, USA.
Sasaki, Y., W.Suzuki, T.Shimada, S.Iizuka, S.Nakamura, M.Nagata, M. Fujimoto, K.Tsuneyama, R. Hokao, K.Miyamoto and M. Aburada. 2009. Dose dependent development of diabetes mellitus and non-alcoholic steatohepatitis in monosodium glutamate-induced obese mice. Life Sci 85:490- 498.

Selvakumar, E., C. Prahalathan, P.T.Sudharsan and P.Varalakshmi. 2006. Chemoprotective effect of lipoic acid against cyclo phosphamide-induced changes in the rat sperm. Toxicology 217:71-78.

Sforcin, J. M. 2007. Propolis and the immune system: a review. Journal of Ethnopharmacology 113(1):1-14.

Singh, P., K.A. Mann, H.K. Mangat and G.Kaur. 2003. Prolonged glutamate excitotoxicity: effects on mitochondrial antioxidants and antioxidant enzymes. Mol. Cell Biochem. 243(2): 139-145.

Stajn, A., R.V. Zikic, B.O. gnjanovic, Z.S.Saicic, S.Z. Pavlovic, M.M. Kostic and V.M.Petrovic. 1997. Effect of cadmium and selenium on the antioxidant defense system in rat kidneys. Comp Biochem Physiol C, Pharmacol Toxicol Endocrinol 117:167-172

Steel, R. G. D. and J. H.Torrie. 1981. Principle and Procedure of Statistics. A Biometrical Approach, second ed. Mc Gvaus-Hill Booh Company, New York, USA.

Tawfik, M.S. and N.Al-Badr.2012. Adverse Effects of Monosodium Glutamate on Liver and Kidney Functions in Adult Rats and Potential Protective Effect of Vitamins C and E. Food and Nutrition Sciences 3: 651-659.

Thomas, M., K.S.Sujantha and S.George. 2010. Protective effect of Piper longum Linn. On monosodium glutamate induced oxidative stress in rats. Physiol Behav 99:334342.

Vinodini, N. A., A. K.Nayanatara, C. Ramaswamy, V. R. Anu, D. K.Rekha, G. K. M.Damadara, B. Ahamed and R.B. Shabarinath. 2010. Study on evaluation of monosodium glutamate induced oxidative damage on renal tissue on adult wistar rats," Journal of Chinese Clinical Medicine 5(3): 144-147.

Yagi, K. 1987. Lipid peroxides and human disease. Chem.phys lipid 45:337-351. 


\section{الملخص العربي \\ التأثيرات الوقائية المحتملة للبرويوليس تجاه السمية الكبدية والكلوية المستحثة بأحادى جلوتامات الصوديوم في الأرانب}

مختار إبر اهيم يوسف، دعاء السيد النساج، محمود حسين جاسر ، علاء فتحى محمد إبر اهيم

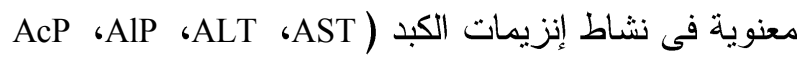
(LDH و GGT ، و مستوى الجلوكوز و اليوريا و الكرياتينين

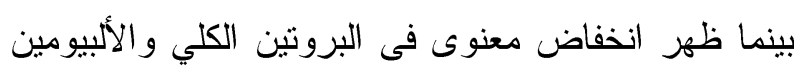

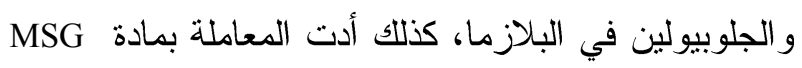

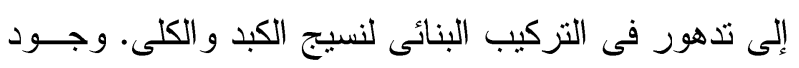

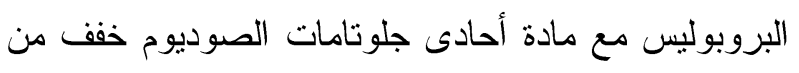
الآثار السامة لمادة MSG على الكبد و الكلى، و هذه الحماية قد

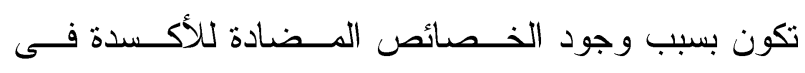
البروبوليس، وقد تم دعم النتائج البيوكيميائية بو اسطة النتائج المتحصل عليها من خلال فحص نـسيج الكبـــــ و الكلــى.

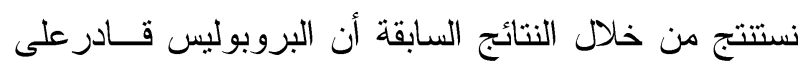

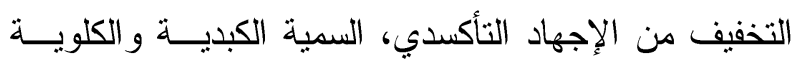

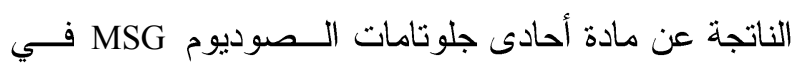

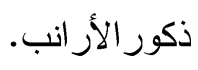

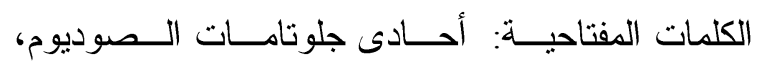

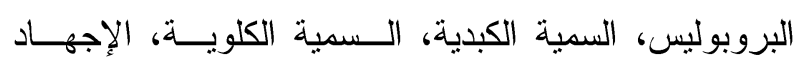

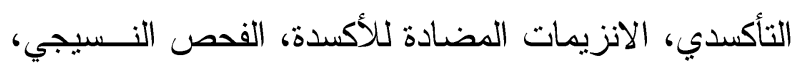

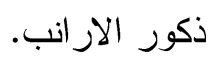

تستخدم مادة أحادى جلوتامات الصوديوم (MSG) كمادة

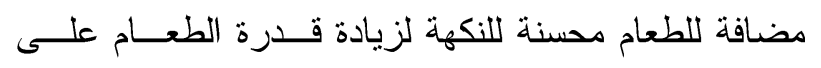

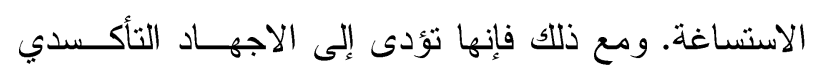
وتسبب العديد من المضاعفات الصحية. فى هذه الدراسة تم

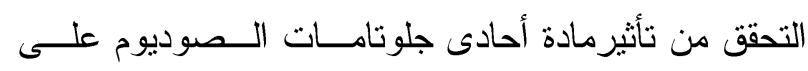

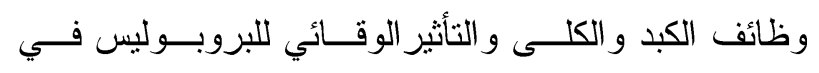

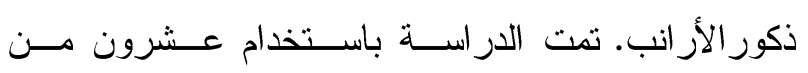

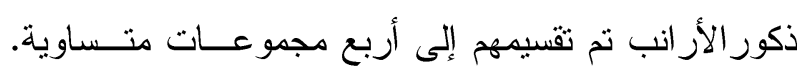
المجموعة الأولى استخدمت كمجموعة ضابطة، المجموعة

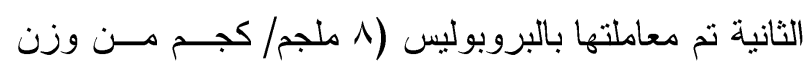

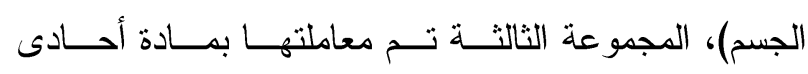

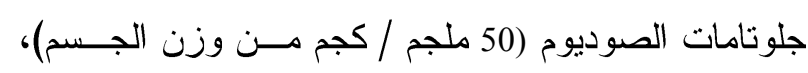

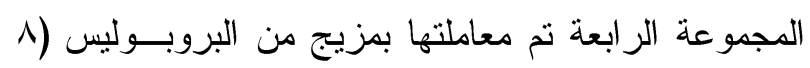

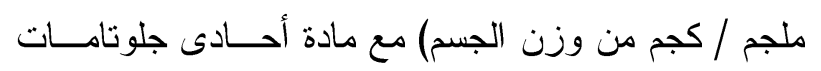

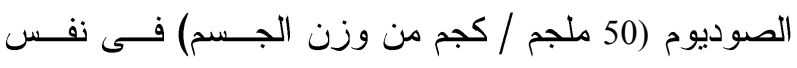

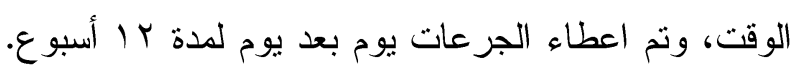

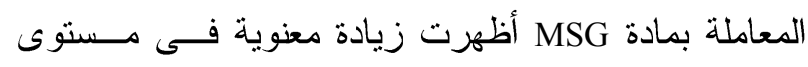
TBARS

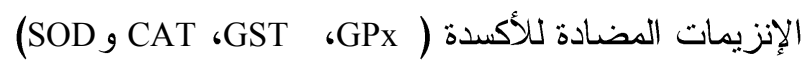

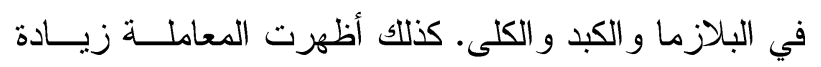

